\title{
The Process of Managing a Destination in Lower and Upper Austria
}

\author{
Markéta Bobková / e-mail: mar.novotna@mail.muni.cz \\ Department of Regional Economics and Administration, \\ Faculty of Economics and Administration, Masaryk University, Brno, Czech Republic
}

Bobková, M. (2015). The Process of Managing a Destination in Lower and Upper Austria. Czech Journal of Tourism, 4(1), 5-25.

DOI: 10.1515/cjot-2015-0001.

\begin{abstract}
The focus of the submitted article is to introduce the findings of author's research in the area of destination management process conducted in the developed (Alpine) tourist destinations in the year of 2014. The theoretical part based on a literature review summarizes current knowledge dealing with the destination management process in terms of approaches and research findings. Problems influencing either positively or negatively this process, e.g. financing, legislation or cooperation among stakeholders are also defined. The practical application part includes an analysis of model destinations in Lower Austria and Upper Austria and presents the results of qualitative research conducted in these destinations. The collected information can be used to design methods leading to the improvement of the destination management process in tourist less developed destinations.
\end{abstract}

\section{Keywords}

Destination, management process, Austria, financing, legislation

JEL classification: L83, O20, G30/ Accepted: 2 November 2015 


\section{Introduction}

Destination management is considered to be one of the most important issues of interest to many researchers working in tourism. Along with other elements, it indeed represents an important component for sustainability and competitiveness of the destination. In the context of tourist destination competitiveness and its sustainable development, the Destination Governance approach should be taken into consideration. The concept of the network-based Destination Governance describes a form of self-organization of tourist destinations, based on the cooperation of the persons and companies involved and shaped by the institutional context as well as rules of organization (Pechlaner, Raich \& Beritelli, 2010).

The need to coordinate individual subjects operating within the destination results from experience of tourism developed countries, especially the Alpine regions. Stakeholders involved in this area are able to overcome obstacles and increase efficiency of destination management by means of mutual cooperation of all service providers (Holešinská, 2007). With respect to domestic tourism, destinations in the Czech Republic are facing a major problem related to effective organization and successful promotion of the destination. Due to a significant level of competition, cooperation of subjects in individual tourist regions is necessary. Holešinská (2007) points out at the fact that organization and conceptual management of tourism represent a fundamental barrier of development.

Metelková (2005) believes that these current problems are caused by low efficiency of cooperation and management, insufficient involvement of private entities in the process of management, deficiencies in legislation and tax systems and ultimately, by limited financial resources. In her research, Holešinská (2012) partly dealt with evaluation of factors affecting management of destination. Her research which was conducted among the Czech destination management organizations shows that these organizations consider financing from private sources as very difficult. According to them, sources of financing are also involved in dominant factors affecting management of tourism in the destination. Holešinská (2013) also points out that destination management does not have a long tradition in the Czech Republic. Although numerous tourism organizations have been established, their identification as destination management organizations (DMOs) is questionable, especially considering the length of cooperation development in the Alpine regions (Holešinská, 2013).

This article is aimed to indicate knowledge of the developed tourist destinations on the basis of author's own research, while regarding the process of destination management and its improvement in terms of quality. Since Austria is considered as a developed country in terms of tourism and it lies very close to the Czech Republic in terms of geography and history, the research was focused on two Austrian Bundeslands (states), specifically the regions of Lower and Upper Austria.

The article is also aimed to introduce a theoretical basis summarizing the findings relating to the process of destination management. Another part constitutes author's own methodology of research and description of data collection. Finally, there are the results 
of qualitative research conducted in the selected destination companies in Austria. In order to use the results of this survey for the identification of factors that affect quality related to the process of destination management, and also in order to propose actions leading to the improvement of the process of destination management in the Czech Republic, it is necessary to establish several research questions:

- How does valid Austrian legislation in the field of tourism affect the process of destination management?

- Does this legislation affect the process of the allocation of financing resources and financial flows?

- What factors affect the implementation of commercial activities?

- How is this process affected by cooperative activities and partnership?

- What circumstances represent the greatest challenge for destination management and improvement of its process?

\section{Theoretical basis}

Holešinská (2012) predominantly sees the beginnings of destination management theory in Austrian literature (Bratl \& Schmidt, 1998) and Swiss literature (Bieger, 2008) which is mainly based on practical research. She also considers beneficial the findings of the Anglo-Saxon authors dealing with destination management (Pearce, 1992; Jenkins, 2000; Ritchie \& Crouch, 2003).

Bratl and Schmidt (1998) are among important Austrian authors focusing on destination management. They focus on practice of destination management in Austria and Switzerland, including the process of its creation. The theoretical results of destination management are becoming the subject of interest to Bieger (2008). Bieger, Laesser and Beritelli (2007, 2011) explored the structure of Swiss tourism organizations in order to find the most appropriate structures of destination management. Regarding the German-speaking authors who dealt with destination management, Pechlaner, Weiermair and Laesser (2002) can be named. They consider destination management as a tool to improve international competitiveness. Besides the aforementioned Bieger (2008) and Bratl and Schmidt (1998), the factors affecting operation of destination companies and process of their management are also dealt with by Pechlaner and Tschurstchenthaler (2003).

As far as the Anglo-Saxon authors writing about the issue of destination management are concerned, Ritchie and Crouch (2003) can be mentioned. They deal with the factors affecting competitiveness of tourist destination. In their studies, they develop a concept of destination management as a part of model related to competitive destination. Another Anglo-Saxon author, Jafari (2000), describes destination management as the integrated process of managing tourist destination. The need to adequately manage the destinations is also explored by Page (2007). The success factors in tourism in terms of a destination management organization are explored by Bornhorst, Ritchie and Sheehan (2010). 
In the Czech literature, the issue of destination management is primarily dealt with by Srb (2003) who considers effectiveness of destination management mainly in close cooperation among organizations, then Metelková (2005), Nejdl (2007, 2010) and Holešinská $(2007,2012,2013)$ who views the destination in terms of supply and demand and identifies weaknesses and opportunities for further development of the Slovak and Czech tourism organizations (DMOs), or also Palatková (2011) who specializes in destination marketing. The factors which affect effectiveness of destination management are examined especially by Srb (2003) and Holešinská (2012).

This article deals with destination management as a management process. The process of managing tourist destinations is normally affected by many factors related to specificity of the destination as a subject of management. The process of management, or management mechanism, can be imagined as a system of the interrelated subsequent activities and tasks that are carried out in order to achieve the objectives set (Holešinská, 2007). The process consists of a variable number of phases; whereas most authors agree on four basic phases generally include planning, organizing, leading and controlling. Page (2007) points out that the destination as a collective producer must be adequately controlled.

Destination management should be seen as a multilayer process because of different markets and interest groups (residents, visitors, businesses) with various requirements. The individual markets are in this process intertwined at different levels and at different times (Page, 2007). Bieger (2008) says that a simplified model of business can be used for an explanation of management activities and processes in the destination because of the fact that destination is a competitive unit that provides services with people and technologies for a payment. Holešinská (2007) sees the main target of destination managers as well as managers in private corporations in ensuring a long-term competitiveness in the market. However, she also points out that confusion about the responsibility for managing the destination may arise. As Nejdl (2010) says, the process of managing destination is based on the principle of cooperation, evaluation and use of the resulting positive impacts to create a specific added value. The literature dealing with tourism management identified in the past years a shift towards the concept of governance where responsibility for policy making extends to both public and private sectors (Dredge, 2006). This concept is based on cooperation and relationships between stakeholders, which are examined by the theory of inter-organisational cooperation (Alter \& Hage, 1993). The governance in tourism can be also expressed as a mutual dependency between governments and private tourism industry (Nordin \& Svensson, 2007). In the destination, public sectors and private organizations interact with each other, and they are all interdependent on resources. The conclusion reveals that the public-private relationships based on trust, sharing risk, informal structure and strategic consensus have a positive influence on the development of tourism destination (Zhang \& Zhu, 2014).

Owing to the cooperation between different actors (e.g. institutions, companies, inhabitants), a network-based destination has to develop a governance process, which requires constant political negotiations, continuous learning, and a business model with high tolerance for trial (Gursoy, Saayman, \& Sotiriadis, 2015). Bornhorst, Ritchie and 
Sheehan (2010) include relationships among suppliers, management efficiency, strategic planning and focus on the objectives of the factors which affect the management process and success of destination management organizations. The authors also mention the fact that the people involved therein can support their success with effective cooperation and coordination. The importance of financial resources in the field of destination management as well as improvement of processes is undoubtedly crucial. In the context of financing cooperative tasks, some aspects affecting willingness of individuals to participate in co-financing can be identified. Therefore, it may be desirable to establish a legal framework, particularly tax laws and regulations (Bieger, 2008).

Proportion of individual companies in financing process should be graded on the basis of incomes earned by them in tourism (Pechlaner \& Tschurtschenthaler, 2003). These authors also say that it is about the sole responsibility of tourism policies to create a basic structure for collection or determination of these charges. Those who pay the charges shall, however, be given the right of co-decision related to the use of the received funds.

Bieger, Laesser and Beritelli (2011) present Swiss destinations as a useful example of financing method. Their financing structure achieves various mixtures of sources, including public financing resources, federal or regional subsidies, resources taken from services provided and resources taken from other business activities. By using this variety of financing resources, it is possible to avoid dependence on unstable forms of financing such as various recreational fees.

Pechlaner, Weiermair and Laesser (2002) created a concept of the so-called performance contract in which tasks of destinations are proposed and funded in various ways according to performance system. The management of public objectives - and associated financing - shall ideally be done on the basis of a performance contract between providers of funds (State) and beneficiaries (tourist organizations) in the form of multi-year framework or annual contracts with the clearly defined objectives and measures.

With respect to the Czech local authors, the model of financing in real conditions of the Czech Republic is, for example, dealt with by Holešinská (2012). Srb (2003) says that the financing criterion fundamentally affects the functioning and stability of the control process. He also illustrates various uses of resources and different principles of financing related to a destination company. Šauer (2008) deals with the issue of the use of various public sources and grants.

From the importance point of view of quality management and successful improvement of performance of a tourist destination, it is also useful to mention the study by Kozak and Baloglu (2011) which presents a draft concept of comprehensive quality management applied to the area of the destination. They are also interested in benchmarking. With regard to the quality in tourism, Bieger (2008) follows Porter's model of tourist diamond. He extended it by the environment affecting competitiveness of a destination. 


\section{Methodology}

Within the research itself, experience in destination management process is presented. The examined model destinations are from Lower and Upper Austria (Table 1). Austria is one of the advanced tourist destinations with developed cooperation and sophisticated legislation. These two lands were also selected on the basis of geographical proximity and the resulting cooperation with some Czech destination management organizations.

Table 1 Tourism organizations in Lower and Upper Austria

\begin{tabular}{|c|c|c|c|}
\hline \multicolumn{4}{|c|}{ Lower Austria } \\
\hline DMO & Director & Town & Websites \\
\hline Niederösterreich Werbung & Christopher Madl & St. Pölten & http://www.niederoesterreich.at \\
\hline Donau Niederösterreich & $\begin{array}{l}\text { Bernhard } \\
\text { Schröder }\end{array}$ & Spitz & http://www.donau.com \\
\hline Mostviertel & Andreas Purt & Wieselburg & http://www.mostviertel.info \\
\hline Waldviertel & \begin{tabular}{|l|} 
Andreas \\
Schwarzinger
\end{tabular} & Zwettl & http://www.waldviertel.at \\
\hline Weinviertel & \begin{tabular}{|l|} 
Hannes \\
Weitschacher
\end{tabular} & Poysdorf & http://www.weinviertel.at \\
\hline Wiener Alpen & Markus Fürst & Katzelsdorf & http://www.wieneralpen.at \\
\hline Wienerwald & Stefan Gabritsch & Purkersdorf & http://www.wienerwald.info \\
\hline \multicolumn{4}{|c|}{ Upper Austria } \\
\hline DMO & Director & Town & Websites \\
\hline Oberösterreich Tourismus & $\begin{array}{l}\text { Andreas } \\
\text { Winkelhofer }\end{array}$ & Linz & http://www.oberoesterreich-tourismus.at \\
\hline Böhmerwald & Reinhold List & Aigen & http://www.boehmerwald.at \\
\hline Ferienregion Attersee & $\begin{array}{l}\text { Christian } \\
\text { Schirlbauer }\end{array}$ & $\begin{array}{l}\text { Attersee am } \\
\text { Attersee }\end{array}$ & http://attersee.salzkammergut.at \\
\hline Bad Hall - Kremsmünster & Martin Selinger & Bad Hall & http://www.badhall.com \\
\hline $\begin{array}{l}\text { Nationalpark Region } \\
\text { Ennstal }\end{array}$ & $\begin{array}{l}\text { Sandra } \\
\text { Kraushofer }\end{array}$ & Reichraming & http://www.nationalparkregion.com \\
\hline Vitalwelt & Karin Pernica & Bad Schallerbach & http://www.vitalwelt.at \\
\hline Inneres Salzkammergut & Pamela Binder & Bad Goisern & http://dachstein.salzkammergut.at \\
\hline S'Innviertel & Gerald Hartl & Geinberg & http://www.innviertel-tourismus.at \\
\hline Mondsee-Irrsee & Thomas Ebner & $\begin{array}{l}\text { Mondsee am } \\
\text { Mondsee }\end{array}$ & http://mondsee.salzkammergut.at \\
\hline Mühlviertler Alm & Klaus Preining & Unterweißenbach & http://www.muehlviertleralm.at \\
\hline Mühlviertler Kernprovincial & Karl Steinbeiß & Freistadt & http://www.muehlviertler-kernland.at \\
\hline Pyhrn-Priel & Thomas Scholl & Windischgarsten & http://www.urlaubsregion-pyhrn-priel.at \\
\hline
\end{tabular}




\begin{tabular}{|l|l|l|l|}
\hline \multicolumn{1}{|c|}{ DMO } & \multicolumn{1}{c|}{ Director } & \multicolumn{1}{c|}{ Town } & \multicolumn{1}{c|}{ Websites } \\
\hline St. Georgen im Attergau & Petra Gangl & $\begin{array}{l}\text { St.Georgen im } \\
\text { Attergau }\end{array}$ & http://attergau.salzkammergut.at \\
\hline Steyrtal & Eva Lubinger & $\begin{array}{l}\text { Steinbach an der } \\
\text { Steyr }\end{array}$ & http://www.nationalparkregion.com \\
\hline TraumArena & Werner Pürmayer & Schönegg & http://www.traumarena.at \\
\hline Ferienregion Traunsee & Andreas Murray & Gmunden & http://traunsee.salzkammergut.at \\
\hline Seelentium & Wolfgang Reindl & Franking & http://www.seelentium.at/ \\
\hline Almtal & Stefan Schimpl & Vorchdorf & http://almtal.salzkammergut.at/\#oben \\
\hline
\end{tabular}

Source: Novotná (2014), updated

In this research, the factors affecting the process of managing and operation of a destination are monitored. The examined factors, those established on the basis of criteria compilation of Srb (2003) and Holešinská (2012), include:

- financing from private sources;

- financing from public resources;

- involvement of business sector;

- implementation of non-profit activities;

- implementation of profitable activities;

- legislative framework.

The empirical method in form of a questionnaire survey was used. It was a structured questionnaire focused on problematic areas of destination management, especially on processes, legislation and financing. The survey was aimed to evaluate foreign experience and also identify possible factors that would lead to the improvement of these problems in the Czech Republic. The questionnaire included both closed and open questions and a possibility of a respondent to comment on relevant issues in own words. To ensure the validity of investigation, a preliminary research with representatives of the Regional Management Weinviertel was also conducted. During the preliminary research, an analysis of written records was used. This method is considered as one of the basic qualitative research methods. The data collected from the questionnaire survey performed in Lower and Upper Austria and from the preliminary research were compared and analysed.

The selected respondents were contacted via electronic mails. The database of electronic addresses was created by using the Internet. The research is aimed at the tourist associations in Upper Austria, the so-called Mehrgemeindige Tourismusverbände (MTV), and regional tourist organizations in Lower Austria. In addition to these entities operating at the regional level, provincial organizations of both federal Lands were also approached; Oberösterreich Tourismus in Upper Austria and Niederösterreich Werbung in Lower Austria. These two survey respondents represent key performers of tourism and providers of public support leading towards the development of tourism. The 
resulting group of respondents altogether consisted of two provincial organizations, six regional organizations from Lower Austria and sixteen associations from Upper Austria, altogether about 24 organizations.

The questionnaires were distributed in two phases. The first phase was launched on 22 October 2013 and its duration was set for the end of November 2013. The respondents were again prompted to fill in the questionnaires on 22 January 2014, with a planned completion of data collection by the end of February. The overall return rate of these questionnaires was $42 \%$.

The data obtained from the questionnaire survey were in most cases processed into the form of clearly readable box plots which provide a more accurate data interpretation (Figure 1). This box plot is based on a rectangle with edges corresponding to values of lower and upper quartile. The interior of the rectangle represents $50 \%$ of the group values. In the rectangle, the line indicates a median line and the round indicates an arithmetic average. Furthermore, there are the minimum values indicated at the lower end and the maximum ones indicated at the upper end, both appeared in respondents' answers for each question. Some values may coincide, depending on the distribution of answers. In the questionnaires, a five-point scale was usually used.

Figure 1 The structure of the box plot
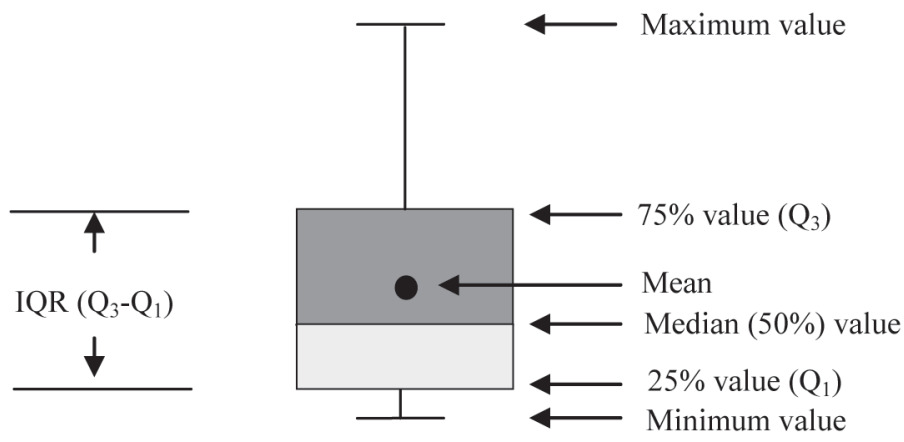

Source: author's own processing

\section{Results}

The results of the survey present problems influencing the destination management process. Likewise, it clarifies the stakeholders' perception of legislation and their views on the issue of financing and definition of financial flows.

The graphical outputs and analyses provide summary results of the questionnaire survey for all respondents. The additional comments address any noticeable nuances of opinions among provincial organizations or destinations in a certain Bundesland (state). They were provided by seven respondents. 
According to the structure of this questionnaire survey, the outputs can be divided into six categories of problems related to destination management and corresponding well with the mentioned factors influencing the process of destination management. The first category is represented by the area of destination management and by related obstacles. The second category is represented by legislation of tourism and its impact on different areas in the management process. The third category focuses on the methods of financing and conditions for grants. The fourth category clarifies the importance of commercial activities as another factor influencing the process of control. The fifth category which includes cooperation and partnership shows the level of involvement of business sector and other stakeholders. And the sixth category contains the total of knowledge related to improvement of managing processes as perceived by representatives of the Austrian destinations.

\section{Destination management}

According to Figure 2, the hardest thing for the destination management organizations was mostly the overcoming of distrust of entrepreneurs $(\mu=3.43)$. The problem of a lack of funds was placed as a difficult-to-overcome factor in the second place $(\mu=3.30)$. The issue of dealing with problems caused to destinations by legislation is considered by the respondents as an easier task $(\mu=2.63)$. The obstacles associated with a lack of awareness of stakeholders are considered as the easiest manageable factors of those mentioned therein $(\mu=2.38)$. Then the respondents should have stated a number symbolizing the importance of an indicator for management of their organization/association to each factor. However, there were rather inconsistent data in this case. It is therefore not possible to determine the importance of individual indicators from the research. The results can be supplemented by the findings from the research of Holešinská (2012) which indicate financial resources and consequently, the legislative framework such as the factors with a dominant impact on management.

In this category, the respondents often overstressed inspiration by other tourist destinations where destination management has been functioning for a longer period of time, as well as a certain form of cross-border partnership between the Länder (states) in Austria. Moreover, the respondents mentioned ongoing benchmarking activities with other tourism organizations. They also emphasized creation of partner networks in the association of Destination Management Monitor Austria which brings together representatives of destination companies from Lower Austria, Carinthia, Styria and Vorarlberg. The main benefit of this partnership is based on the exploration of practical management examples.

\section{Legislation}

The main aim of this section is to focus on the effect of legislation on individual activities related to the management process and on different aspects of DMO functioning, 
Figure 2 Overcoming of management problems

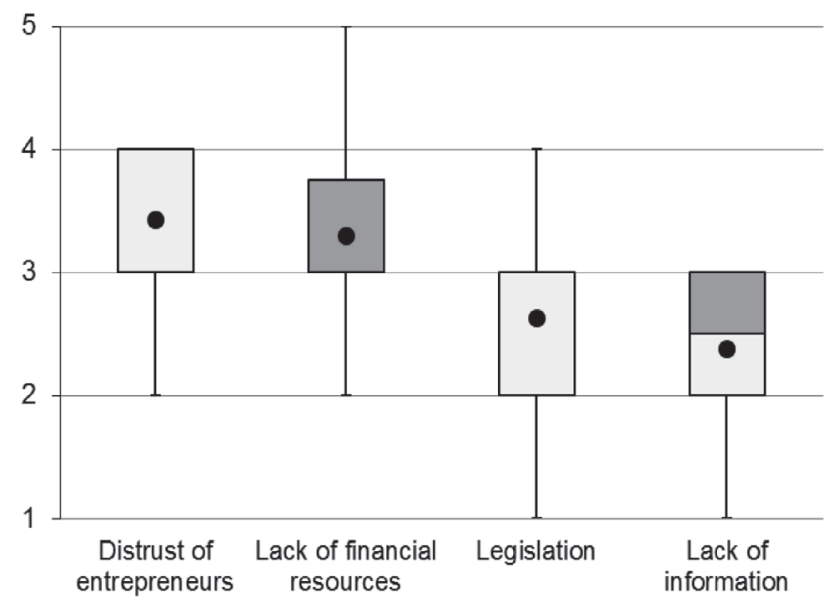

Rating Scale: 1 = easy to overcome; 5 = very difficult to overcome

Source: Novotná (2014)

Figure 3 Influence of legislation on different aspects of DMO functioning

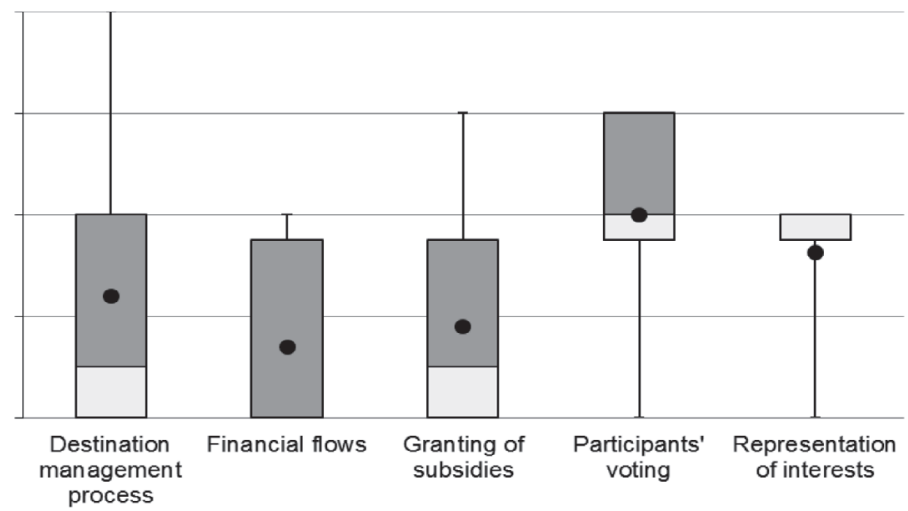

Rating Scale: 1 = great influence; $5=$ no effect

Source: Novotná (2014) 
as perceived by respondents. Figure 3 describes this effect of legislation which is widely considered to be a tool for regulating tourism.

According to the separately taken results of the questionnaire for each Land, perception of the impact of legislation on regulation in Upper Austria is not as clear as in Lower Austria where $100 \%$ match in this respect is experienced. The organizations in Lower Austria absolutely agree on a considerable influence of the legislative on the process of management and financial flows. The results were not so consistent in Upper Austria. This fact is obvious while observing a distribution of values shown in the graph. The distribution was influenced by answers of some Upper Austrian associations which decreased the influence of legislation on the management process $(\mu=2.20)$. The legislation still retains the sufficiently great importance in this meaning. The total sum of the acquired data shows that the legislation significantly affects financial flows $(\mu=1.70)$ and granting of subsidies $(\mu=1.90)$. The legislation shows the lowest impact, but still moderate, on representation of interests $(\mu=2.63)$ and voting related to decision making $(\mu=$ $3.00)$. In conclusion, the highly correlated connection is between the legislation and the financial flows.

\section{Financing and grants}

This category focuses on the methods of financing and possibility of obtaining grants because the financial resources represent an important factor affecting tourism management. Figure 4 represents the factors affecting the process of grant acquirement. Here, similarly like in the previous section, one can see the importance of legislation $(\mu=1.63)$ which is agreed by the respondents across both provinces. The purpose for which the subsidy is provided has also a considerable impact $(\mu=1.90)$. The possibility of monitoring the ways of use also significantly contributes to a chance of subsidy acquirement $(\mu=2.10)$. Other results show a distribution of responses across the rating scale. The minimum consensus between the organizations and associations occurs in the case of evaluation of the factor related to the project duration $(\mu=3.10)$, return of a grant $(\mu=$ 2.89) and problems with an administrative burden $(\mu=3.00)$.

In open questions, respondents mostly said they received subsidies from Land Government, either from provincial funds or from the Chamber of Commerce, or also from the European funds. The associations and organizations thus use the obtained funds for the implementation of various regional projects that arise in cooperation with partners. They also spend them on marketing activities. The provincial organizations involved in tourism divide the funds for product development as well as support and development of marketing measures, consulting services for organizations, training and further education of employees. If the subsidies are not granted, the destinations are forced to choose an alternative method of financing. To finance their management, they spend resources that are generated by revenues of cooperation or selling of services and products of tourism. They also use other private resources or form of sponsorship. However, most respondents point out that if a major part of grant funds is not granted, 
then other development activities are not allowed to be run due to the fact that other financial sources cannot cover them. Projects are therefore hardly feasible unless having additional support.

Figure 4 Factors influencing the process of subsidy acquirement

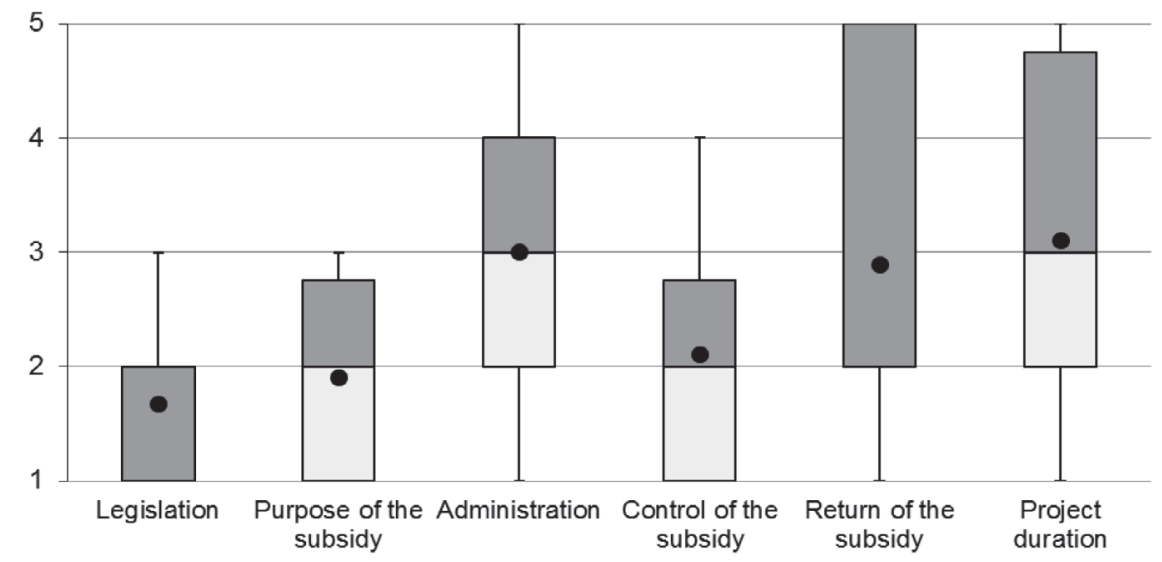

Source: Novotná (2014)

Rating Scale: 1 = great influence; 5 = no effect

The respondents express their positive opinion on legislation-provided mechanism of redistribution of charges among businesses, municipalities and provincial organization. They think the key leading to an allocation of funds among municipalities is transparent and equitable.

\section{Commercial Activities}

The fourth category clarifies the importance of commercial activities for the process of controlling a tourist destination, while pointing out the components that affect the implementation of these activities. Holešinská (2012) speaks about a dominant influence of commercial activities on the process of controlling tourism. On the other hand, she has also found that the implementation of profitable activities means a difficult task for some Austrian and Czech destination management organizations. However, she adds that the implementation was best evaluated by those companies which were carrying out commercial activities and which were simultaneously selling tourism products in direct ways. This is what the destination organizations of Lower Austria and Upper Austria comply with, according to the findings of this research. The income from commercial activities may be a major source of financing for them, applicable to improve quality of services and management process itself. 
The implementation of commercial activities is greatly affected by cooperation with entrepreneurs $(\mu=1.50)$. The financial sources have traditionally a big influence $(\mu=1.70)$; they represent an initial investment imposed for the previous creation and promotion of a product related to tourism. Furthermore, it is, however, assumed that commercial activities will generate profits, which will expand possibilities of financing of other activities, including support of management and development of tourism in a destination. The cooperation with municipalities also represents significant importance for the implementation of commercial activities $(\mu=1.80)$. Emphasis on the cooperation with municipalities and entrepreneurs in commercial activities is primarily imposed by organizations of Lower Austria. Some of the Upper Austrian associations do not find this factor so important.

Thelowestinfluencein this field was achieved by thelegalform oforganization/association $(\mu=3.20)$, surprisingly even in Lower Austrian organizations; this time it was also legislation $(\mu=3.13)$. Both provincial organizations were not consistently able to determine the importance of legislation for carrying out commercial activities.

On the other hand, the provincial organizations were not able to agree on the impact of legal forms. This impact is undeniable for the Lower Austrian organization, while the Upper Austrian organization considers it to be utterly meaningless. The exact distribution of values related to these factors is mentioned in Figure 5.

The legal forms of organizations and associations in Lower and Upper Austria are established by law. These legal forms in Lower Austria went through such development that they changed their status from the initial public corporations, which are still used in Upper Austria, to the shape of companies of business type (Ltd). Tourism organizations themselves see the main advantage of this change that they are able to operate well and act quickly on the market as the companies with limited liability, which increases their competitiveness. They consider this form more flexible, leading to more professional decisions. This is the legal form used by the entities which are oriented to profit.

However, Srb (2002) says that this legal form is rather more typical of mature forms of destination management in developed tourist destinations or also for the entities which are established by private companies.

However, the research results do not show that the chosen legal form would have a major impact on the implementation of commercial activities. This attitude of destination companies may be caused by the fact that the organizations and associations have such legal forms that allow carrying out the commercial activities without any major difficulties. It may also be caused by their experience and level of development in relation to commercial structures.

As the respondents say, providing an active position in the market is linked to the performance of commercial activities at most. There are also activities performed in the area of services provided to partners and sales of promotion materials. The organizations and associations also act as travel agents; they make reservations, sell tickets and provide tourist packages, including overnight stays, sports and additional services. The provincial organization called Oberösterreich Tourismus mentioned consulting services and provision of training services in the field of tourism as profitable activities, too. 
Figure 5 Influence of the factors on the implementation of commercial activities

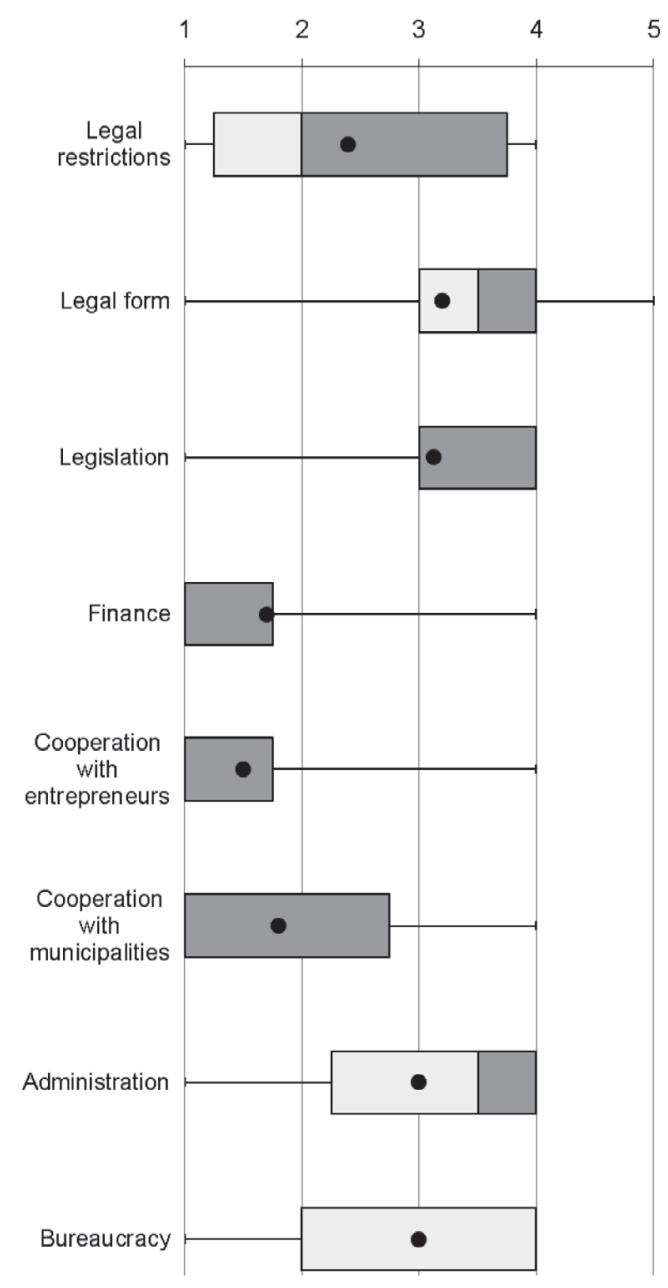

Rating Scale: 1 = great influence; 5 = no effect

Source: Novotná (2014)

\section{Cooperation and partnership}

The fifth category contains the issue of cooperation and partnership. It is also aimed to demonstrate the level of the involvement of a business sector and other subjects of tourism in the investigated Austrian destinations. Based on the survey results, cooperation with partners in certain activities necessary for the proper functioning of destination management can be assessed (Figure 5). The level of cooperation with other participants in tourism from the perspective of the examined destination management organizations 
can be also evaluated (Figure 6). There were beam-shaped graphs used for the data processing in the partnership area.

Figure 6 below shows that the evaluation of cooperation in the implementation of some activities is at a satisfactory level. The associations and organizations see the best experience of working with other partners in the field of grant applications $(\mu=1.58)$. The cooperation in the field of developing partnerships is very good $(\mu=1.80)$, as well as the ensurance of competitiveness $(\mu=1.85)$, supply coordination $(\mu=1.87)$ and participation in management process $(\mu=2.00)$. With respect to these activities, the worst rating was achieved by the coordination of interests of all participants $(\mu=2.43)$.

As far as the assessment of cooperation with individual subjects (Figure 7) is concerned, the associations and organizations made the best evaluation to other destination management organizations $(\mu=1.56)$. Bundesländer (states) were awarded the second place (1.90). A very good evaluation was given to local entrepreneurs $(\mu=2.00)$, municipalities $(\mu=2.21)$ and provincial (land) organizations $(\mu=2.23)$.

Figure 6 Assessment of cooperation - activities

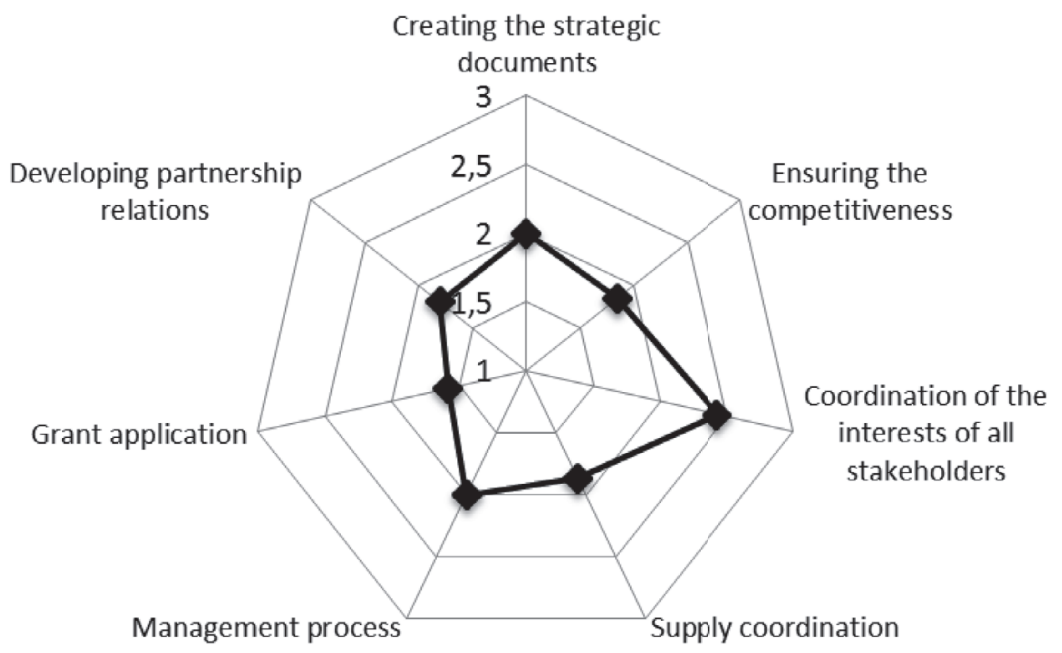

Rating Scale: 1 = excellent cooperation; 5 = insufficient cooperation

Source: Novotná (2014)

In Lower and Upper Austria, partnership is based on contractual as well as free cooperation on joint projects, supported by grouping resources and unified brand. It is also based on mutual trust representing the fundamental stone for cooperation. The support of partnerships is also represented by interconnection across the provincial organizations. Partners often form interest groups in which they implement joint projects and identify joint targets. An important element for the development of these relations is 
mutual communication and constant awareness leading to achieving trust among stakeholders. In the federal states there are some networks created for the purpose of cooperation with other institutions in order to obtain valuable experience and new knowledge. Application of ideas of Bratl and Schmidt (1998) is clearly reflected in practice here. They assume that destination companies can motivate individual destination subjects for mutual cooperation whose condition is to overcome barriers arising due to the contradictory relationship of competition and cooperation among the stakeholders.

Figure 7 Assessment of cooperation - stakeholders

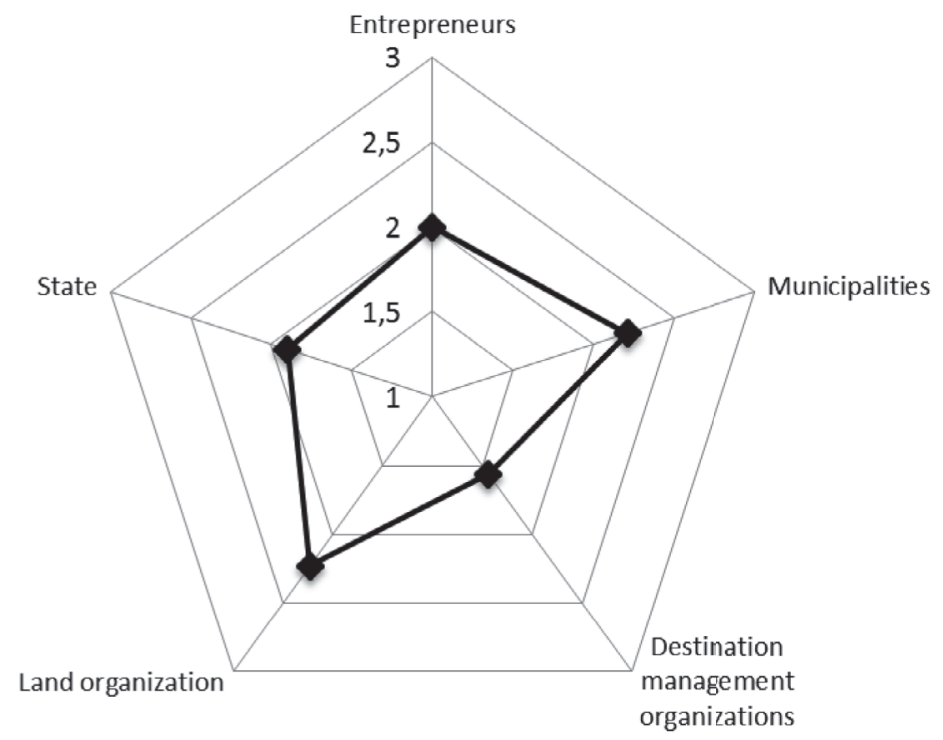

Rating Scale: 1 = excellent cooperation; 5 = insufficient cooperation

Source: Novotná (2014)

\section{Improving management processes}

This section reveals the factors influencing the process of destination management in developed destinations and improvement of this process. The sixth category therefore includes a summary of findings in relation to the influence of the factors leading to the improvement of management processes as perceived by representatives of destinations.

The results of this part of the questionnaire survey shown in Figure 8 indicate that the respondents have substantially similar opinions on the effects of the above-mentioned factors. The question of trust between the stakeholders clearly shows the greatest impact on the management process $(\mu=1.10)$. In the second place, cooperation with subjects of tourism as well as a sufficient level of financial funds act consistently on the processes 
$(\mu=1.20)$. The competences of personnel are equally important $(\mu=1.30)$. Slightly smaller importance is connected to policies and strategy of an organization $(\mu=1.60)$ and legislation $(\mu=1.80)$. However, these values also mean that the last two mentioned factors affect the management process very much.

Figure 8 Influence of the factors on management process

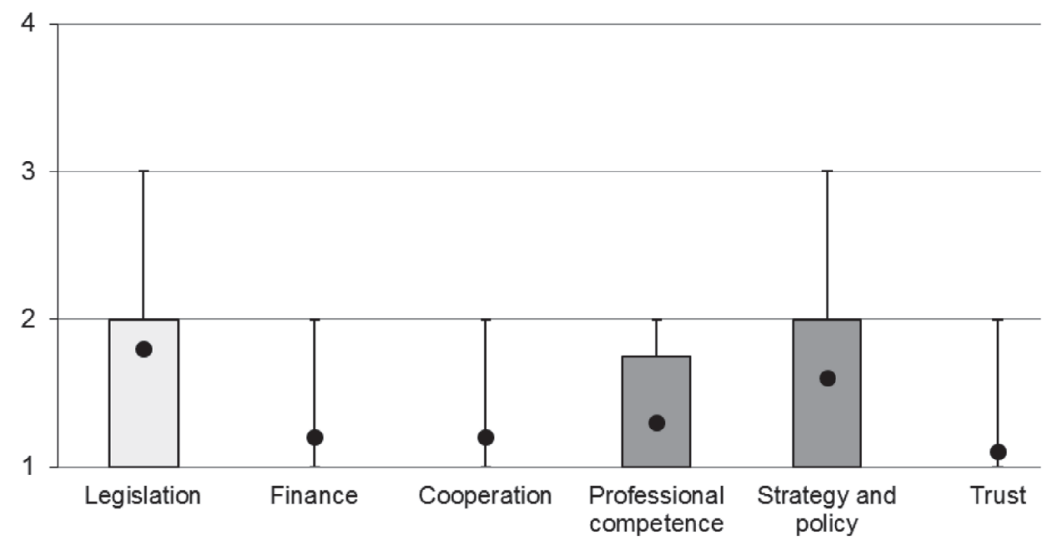

Rating Scale: 1 = great influence; 5 = no effect

Source: Novotná (2014)

Although the differences in the responses are almost negligible and despite the fact that all respondents consider the effect of factors as at least the average one, greater consensus was reached by the tourism organizations of Lower Austria which were giving greater importance to all factors.

One of the open questions the respondents were responsible for concerned the amount of resources typically spent on quality assurance management. The respondents only say that the exact amount is not known to them and that the resources are mostly limited. However, they note that a significant amount is intended for staff training, which also confirms the importance of proficiency for the improvement of the processes of destination management. The resources which are spent come mostly from various support programs, current budgets and funds of the participating entrepreneurs.

\section{Discussion}

According to the questionnaire sent to the respondents in Lower and Upper Austria, six categories were defined. In most of them three factors are constantly mentioned. They can be evaluated as the most important for the process of management and its improvement. These are finance, cooperation and legislative framework. Other mentioned 
factors such as trust and professional competence are complementary or closely related to these three factors.

The question is how the findings of the questionnaire can be applied in the Czech Republic. One of the issues affecting the management process in the Czech Republic is a lack of communication and low effort for cooperation among individual subjects. Cooperation and formation of mutual networks are reflected very positively in the Austrian provinces.

An important element of destination management whose importance is highly recognized in Lower and Upper Austria, while absolutely missing in the Czech Republic, is the existence of valid legislation regulating the field of promotion and management of tourism, e.g., such legislation which would obviously contribute to a clearer definition of competences of parties in tourism in the Czech Republic and which would exactly determine the flows of funds generated by tourism as well as their spending on the needs of tourism.

The financial resources affect overall functioning of destination management because they are necessary for a high-quality performance of activities, staff training and promotion of a destination, which also provides greater competitiveness. The Austrian destinations are not so dependent on public resources as the Czech ones although, of course, it also means a heavy burden for them if they do not get any subsidies.

The organizations and associations of tourism in Lower and Upper Austria use the system of financing from multiple sources. They also obtain money from commercial activities whose implementation is easier in Austria. The subscription fees collected from entrepreneurs constitute an important item. This is the way how cooperation with entrepreneurs, their involvement in the management process and their participation in functioning of destination management bring additional financial resources and greater independence from public resources.

\section{Conclusion}

The article dealt with the process of management in destinations of Lower and Upper Austria. First the factors that significantly affect this process were defined at theoretical level. Experts included among these factors especially a lack of the involvement of business sector and a low level of cooperation between entrepreneurs (Srb, 2003). The financial resources represent another problem affecting the quality of management processes. Like with other public goods, individual subjects benefiting from tourism do not have any individual or economic reasons for the provision of financial resources (Bieger, 2008). The insufficient financing from private sources is an obstacle for the destination companies which are not established by private entrepreneurs (Holešinská, 2012).

The fundamental part of the article is devoted to the introduction of knowledge of the developed tourist destinations from Lower and Upper Austria. These findings were implemented on the basis of the questionnaire survey carried out in the examined reference destinations. The Austrian destinations were chosen according to the long-time 
experience in the field of tourism and destination management. The survey carried out in the tourist associations and organizations was aimed to identify their own perception of the impact of legislation, financial flows and other components influencing the process of destination management.

The survey shows that the most difficult task for the destination management organizations was to overcome the initial distrust of entrepreneurs and a lack of financial resources. As the respondents say, the existing legislation related to tourism largely affects the financial flows and the allocation of subsidies. The respondents expressed a positive opinion on the legislatively established mechanism of charge redistribution among tourism subjects. They consider it transparent and fair.

Furthermore, the research also focused on the implementation of commercial activities, which is heavily influenced by cooperation with entrepreneurs and municipalities. The organizations and tourism associations most often include making reservations, ticketing and marketing of tourist packages into their commercial activities. Another part of the questionnaire focused on the issue of cooperation and partnership as well as their importance for destination management. On the basis of the survey investigation, partnerships are based on mutual trust or contractual and free cooperation on joint projects. The stakeholders therein also create networks allowing gaining valuable experience and new knowledge.

The cooperation means for the respondents an important factor leading to the improvement of the processes of destination management. For these purposes, they also use the method of benchmarking with other destination management organizations. The quality of management process is therefore affected by mutual trust among the participants as well as by sufficient funding. The respondents also consider professional competence of employees an element of the quality. Therefore, they spend a considerable sum of money on education and training of their personnel.

The experience of Länder (states) as well as the results of the survey can be used as inspiration for the subsequent formulation of processes contributing to the improvement of management process in less developed tourist destinations. According to the above-mentioned findings, the management process could be improved by adopting the legislation that would focus on the area of support and management of tourism, clarify the competences of stakeholders in tourism and regulate the flows of financial resources. Involving the private sector in destination management and greater cooperation with entrepreneurs would lead to the generating of additional financial resources available for better functioning of destination management.

\section{Acknowledgment}

This article was supported by the project Specific University Research at Masaryk University in Brno, Faculty of Economics and Administration, no. MUNI/A/0853/2013. 


\section{References}

Alter, C., \& Hage, J. (1993). Organizations working together. Newbury Park, CA: Sage Publications.

Beritelli, P., Bieger, T., \& Laesser, C. (2007). Destination Governance: Using Corporate Governance Theories as a Foundation for Effective Destination Management. Journal of Travel Research, 46, 96-107.

Bieger, T. (2008). Management von Destination. München: Oldenbourg Wissenschaftsverlag $\mathrm{GmbH}$.

Bieger, T., Laesser, C., \& Beritelli, P. (2011). Destinationsstrukturen der 3. Generation - Der Anschluss zum Markt. St. Gallen: Universität St. Gallen.

Bornhorst, T., Ritchie, B. J. R., \& Sheehan, L. (2010). Determinants of tourism success for DMOs \& destinations: An empirical examination of stakeholders' perspectives. Tourism Management, 31(5), 572-589. DOI: 10.1016/j.tourman.2009.06.008

Bratl, H., \& Schmidt, F. (1998). Destinationmanagement. Wien: Wirtschafts-ministerium, ÖAR-Regionalberatung, GmbH.

Dredge, D. (2006). Policy networks and the local organisation of tourism. Tourism management, 27(2), 269-280. DOI: 10.1016/j.tourman.2004.10.003

Gursoy, D., Saayman, M., \& Sotiriadis, M. D. (Eds.). (2015). Collaboration in Tourism Businesses and Destinations: A Handbook. Bingley: Emerald Group Publishing.

Holešinská, A. (2007). Destinačni management aneb Jak řídit turistickou destinaci (Destination management and How to manage a tourist destination) Brno: Masaryk University.

Holešinská, A. (2012). Destinačni management jako nástroj regionální politiky cestouního ruchu (Destination management as an instrument of regional tourism policy). Brno: Masaryk University.

Holešinská, A. (2013). DMO - A dummy-made organ or a really working destination management organization. Czech Journal of Tourism, 2(1), 19-36. DOI: 10.2478/cjot-2013-0002

Jafari, J. (2000). Encyclopedia of Tourism. London: Routledge.

Jenkins, J. (2000). The dynamics of regional tourism organisations in New South Wales, Australia: History, structures and operations. Current Issues in Tourism, 3(3), 175-203. DOI: $10.1080 / 13683500008667872$

Kozak, M., \& Baloglu, S. (2011). Managing and Marketing Tourist Destinations: strategies to gain a competitive edge. New York/Abingdon: Routledge.

Metelková, P. (2005). Destinačni management v České republice (Destination management in the Czech Republic). Brno: Masaryk University. Retrieved from http://is.muni.cz/do/1456/soubory/katedry/kres/3910085/MSMT_MCR.pdf.

Nejdl, K. (2007). Úvod do problematiky destinačního management (Introduction into destination management). COT Business, (2), 31.

Nejdl, K. (2010). Management destinace cestouního ruchu (Tourism destination management). Prague: Vysoká škola hotelová v Praze 8.

Nordin, S., \& Svensson, B. (2007). Innovative destination governance: The Swedish ski resort of Åre. The International Journal of Entrepreneurship and Innovation, 8(1), 53-66. DOI: 10.5367/000000007780007416

Novotná, M. (2014). Proces ř́zení destinace a jeho zkvalitňování - př́padová studie Rakousko (Destination management process and it improvement - case study Austria). Dissertation. Brno: Masaryk University. 
Page, J. S. (2007). Tourism management. Managing for Change. Oxford: Butterworth-Heinemann.

Palatková, M. (2011). Marketingový management destinaci (Marketing destination management). Prague: Grada Publishing.

Pearce, D. G. (1992). Tourist organizations. Harlow: Longman Group UK Ltd.

Pechlaner, H., Raich, F., \& Beritelli, P. (2010). Destination governance (special issue): Editorial. Tourism Review, 65(4), 3.

Pechlaner, H., \& Tschurtschenthaler, P. (2003). Tourism Policy, Tourism Organizations and Change Management in Alpine Regions and Destinations: A European Perspective. Current Issues in Tourism, 6(6), 508-539. DOI: 10.1080/13683500308667967

Pechlaner, H., Weiermair, K., \& Laesser, C. (2002). Tourismuspolitik und Destinationsmanagement: Neue Herausforderungen und Konzepte. Bern/Stuttgart/Wien: Haupt.

Ritchie, B. J. R., \& Crouch, G. I. (2003). The competitive destination: a sustainable tourism perspective. Wallingford: CABI publishing.

Srb, J. (2002). Návrh modelu řizeni cestovniho ruchu v turistické destinaci Český ráj (Draft model for management of tourism in the tourist destination called Český Ráj). Liberec: Regional Development Agency.

Srb, J. (2003). Řízení turistické destinace a trvale udržitelný rozvoj cestovního ruchu (Tourist destination managing and sustainable tourism development). COT business, 3.

Šauer, M. (2008). Podpora cestovního ruchu z veřejných financi (Support of Tourism from Public Finance). $\mathrm{PhD}$ thesis. Brno: Masaryk University.

Zhang, H., \& Zhu, M. (2014). Tourism Destination Governance: A Review and Research Agenda. International Journal of e-Education, e-Business, e-Management and e-Learning, (4), 2. DOI: 10.7763/IJEEEE.2014.V4.315 